International Journal of Management Science
and Business Administration
Volume 7, Issue 4, May 2021, Pages 14-22
DOI: 10.18775/ijmsba.1849-5664-5419.2014.74.1002
URL: http://dx.doi.org/10.18775/ijmsba.1849-5664-5419.2014.74.1002

\title{
A Study on the Relationships between Authentic Leadership, Job Crafting, Psychological Capital and Organisational Innovation
}

\author{
${ }^{1}$ Rachadatip Uppathampracha, ${ }^{2}$ Liu Guoxin \\ ${ }^{1}$ School of Management, Wuhan University of Technology, Wuhan, P.R. China. \\ ${ }^{2}$ School of Management, Wuhan University of Technology, Wuhan, P.R. China.
}

\begin{abstract}
The financial business industry has a vital role in national economic development. In Thailand, financial businesses practice innovation to develop the organisation. Weighing on this matter, this study examined the impacts of authentic leadership, psychological capital, and job crafting on the organisational innovation of Thailand's financial business sector. Survey questionnaires were distributed to 683 private company employees for example. Multiple linear regression analyses were employed as the data analysis techniques. The findings disclosed a significantly positive relationship between authentic leadership and organisational innovation; the hypothesis was, hence, supported $(\beta=0.61, t=21.49, p=.00)$. Besides, the results showed that psychological capital and organisational innovation had a significant positive relationship, proving the hypothesis $(\beta=0.73, \mathrm{t}=21.89, \mathrm{p}=.00)$. Moreover, job crafting and organisational innovation positively and significantly impacted job crafting and organisational innovation, sustaining the hypothesis $(\beta=0.70, \mathrm{t}=21.33, \mathrm{p}=.00)$. Overall, this study found the relative importance of authentic leadership, psychological capital, and job crafting enhancing organisational innovation. The findings may assist practitioners in business organisations in setting up policies, planning, and strategies. Future research may explore the impacts of multiple sectors and industries as well as add other variables influencing the organisational innovation in the prediction equation. Additional mediating and moderating mechanisms may be needed to advance the relevant knowledge.
\end{abstract}

Keywords: Authentic leadership, Job crafting, Psychological capital, Organisational innovation, Financial business

\section{Introduction}

Financial business organisations play a crucial role in the growth of the country's economy. Financial business organisations must set aside enough funds to meet the needs of business divisions and the general public divisions. Financing business trends in changing business models with innovations help customers more conveniently on various business transactions. Therefore, innovation is necessary for financial business organisations nowadays. For the financial business sector in Thailand, there are five segments: bank, securities, nonbanks, insurance, asset management company.

Financial business organisations in Thailand have tried to restore economic and business potential by creating new inventions, technology, or management methods to create an innovative organisation. The financial business has evolved into a new financial model known as Fintech (Financial Technology). It uses innovation to develop a new financial business form by using online systems in various activities. Consumers can use online to perform multiple financial transactions in their daily life enabling new products and services.

Therefore, financial business sector companies in Thailand need to develop themselves into organisational innovation. Innovation is an important tool for organisations to create opportunities or take advantage of opportunities to grow their businesses (Burns, 2011). And innovation is also an important factor in building business competitiveness (Tidd \& Bessant, 2018). Moreover, innovation is the main key to build a competitive advantage, create marketing opportunities and make an organisation successful (Uejirapongpan et al., 2010).

To develop an organisation into an organisational innovation, it is necessary to have a factor that promotes innovation. Leadership has become a more important issue. In this era, we need real leaders. Many things that have been learned in the past may not be applicable in the present, and more new knowledge is necessary. Leaders must have enough knowledge and must be changed their behaviour for the new business model in organisational innovation. Therefore, authentic leadership is the appropriate leadership style in this study. 
Apart from leadership, psychological capital and job crafting are the vital factors that contribute to organisational innovation. The findings posited that all aspects of innovative action, especially idea support, idea creation, and idea execution, are influenced by psychological capital. Besides, constructive psychological tools enable individuals to create, mobilize, and incorporate creative thinking in their organisations by expanding the thought-action cycle. (Abbas \& Raja, 2015). Van Wingerden et al. (2017) posited that job crafting has a beneficial relationship with performance and can be enhanced with interventions. Thus, psychological capital and job crafting may affect innovation in the organisation.

This study aimed to explore the variables that impact organisational innovation. The construct of authentic leadership was studied as one of the factors. Also, psychological capital and job crafting were added to predict organisational innovation. This study could provide insight into what needs to be done by the employees. The leader does develop a financial business sector company towards an innovative organisation in Thailand's context.

\section{Literature Review Authentic leadership}

Authentic leadership is a form of leadership that is influenced by the concept of reality. The meaning of reality is a process that is independent of one's real self in daily life. (Avolio \& Mhatre, 2012). When a person is a real person, they will understand themselves and accept both their strengths and weaknesses, self-stability, unbiased, and sincere relationships with others, including concepts, philosophy, and values consistent with the behaviour expressed (Kernis, 2003). George (2003) composes that authentic leaders have a deep sensory faculty of guidance for their leadership. Their acts are a continual reflection of their core values. They consider themselves as guardians of the environment. Often, servants and leaders must guide with both their hearts and their heads to build long-lasting organisations. Research on authentic leadership that most studies on the significance of authentic leadership in the organisation or the team with the characteristics and behaviours desired by the followers. Authentic leadership links to many positive outcomes, for instance, psychological well-being (Toor \& Ofori, 2009), work engagement, and job satisfaction (Giallonardo et al., 2010).

\section{Psychological capital}

Psychological capital refers to actions or expressions in which positive individual behaviour is explained through social science (Lopez et al., 2018). Also, psychological capital is a valuable approach to human resource management and development within an organisation (Larson \& Luthans, 2006). Furthermore, psychological capital related to the various positive result, examples include, psychological capital is regarded as a higher-order center build that integrates several positive organisational behaviour criteria (Luthans et al., 2004). Hence, psychological capital is a significant variable that the organisation's management has turned to attention to develop the personnel in the organisation and lead to the effectiveness of the organisation (Luthans \& Youssef, 2004).

\section{Job crafting}

To begin with the background of job crafting, Salancik and Pfeffer (1978) stated that social information system framework connecting the importance of work from the significant task and interpersonal behaviour. They suggested that individuals utilise contextual information of their organisation, for example, cues and norms, to rationalise their determinations and guide their behaviour. Wrzesniewski and Dutton (2001) originated the condition of job crafting as the individuals' physical and psychological improvements in their mission or relationship scopes. Organisations are not handling proactive improvements in job design as well as the manager probably does not even notice what is referred to as job crafting. That is to say, bringing proactive steps and efforts to update the things that employees accomplish at their work, principally evolving tasks, relationships, and perceptions of their works, are all about job crafting (Berg et al., 2008).

\section{Organisational innovation}

Organisational innovation refers to a transformation in the organisation, such as organisational structure, procedures, administrative systems, performance knowledge management, and managerial skills that can motivate them to use resources more successfully. (Damanpour et al., 2009). Tidd and Bessant (2018) stated that organisational innovation has integrated elements to strengthen the environment that leads to innovation throughout the organisation. It has also further added to the organisational innovation as an expression of creativity in the organisation that has been encouraged, supported, giving feedback, and constructive criticism. Based on this definition, organisational innovation is connected to matter, for instance, creativity, knowledge, and learning.

\subsection{Hypotheses development}


For the sake of the essence of innovation in achieving effectiveness, efficiency, and sustainability of an organisation as well as handling the external environment's volatility, academics and practitioners are attempting to identify how and why innovation occurs. There has been a concentration on the innovation which impacts leadership. Various empirical studies have supported the positive influence of leadership and the relationship between a leader and supporter on innovation. (Gumusluoglu \& Ilsev, 2009; Jung et al., 2003). Walumbwa et al. (2008) speculated that authentic leadership support psychological capabilities and an ethical environment that are all positive. To promote greater selfawareness, balanced processing of information, relational transparency, and internalised moral perspective, the role of leaders work together with employees as well as enhancing positive self-development. Besides, Avolio and Gardner (2005) stated that the character of authentic leadership could increase followers' performance outcomes. Authentic leadership supported openness and encourages trust between leaders and followers, which are highly important for innovation (Walumbwa et al., 2008).

What's more, through relationships with subordinates, authentic leadership can also play an essential part in improving innovation (Müceldili et al., 2013). The relational of authentic leadership may foster innovation. According to empirical studies, employees' creative endeavours are influenced by the relationship and degree of the relationship; this, in turn, impacts organisational innovation. (Yuan \& Woodman, 2010). Accordingly, the following hypotheses are proposed and tested:

\section{H1: Authentic leadership is positively related to organisational innovation.}

Psychological capital has been demonstrated to impact an organisation's innovation (Abbas \& Raja, 2015; Rego et al., 2012; Sweetman et al., 2011). Jafri (2012) accepts that employees' innovative behaviour is strongly influenced by psychological capital, including self-efficacy, hope, resilience, and optimism, predicting their innovative behaviour. Innovative behaviour tends to be a significant essence in every organisation to promote organisational innovation. Moreover, innovation is essential for the organisation's effective and efficient performance (Abbas \& Raja, 2015). Sweetman et al. (2011), to explore the impact of psychological capital on innovative performance, it might have been uncovered that psychological capital and its dimensions can also be used to forecast for improve innovative performance. Another study by Hmieleski and Carr (2007) discovered that individuals with high self-efficacy, hope, resilience, and optimism demonstrate more creative and innovative behaviours. These people had a tendency to design, develop, and accomplish innovative thoughts in their work. As a result of the obvious impact of Psychological capital on innovation, a research hypothesis was established:

\section{H2: Psychological capital is positively related to organisational innovation.}

It is accepted that job crafting behaviours would primarily be connected with positive results since extremely enthusiastic workers that are changing skilled in their working environment would probably add higher to contribute to the organisation positively (Bakker \& Demerouti, 2007). Likewise, by moving forward person-job fit, job crafting behaviours put employees in a better position to accomplish better results as well as a better state of well-being. (Kooij et al., 2017). Similarly, this positive relationship might have been discovered in a quasi-experimental analysis that a job crafting approach had a beneficial impact on worker well-being (Van Wingerden et al., 2017). Besides, job crafting behaviours produce positive organisational outcomes and contribute to improved job performance (Robledo et al., 2019). To conclude, the importance of job crafting as a general concept is caused by a positive mental state rather than a negative mental state (Robledo et al., 2019). Job-crafting behaviours lead to various positive results, for example, work engagement, job satisfaction, resilience, and thriving (Berg et al., 2008). Therefore, Job crafting may lead to organisational innovation. Hence, the following hypothesis was examined:

\section{H3: Job crafting is positively related to organisational innovation.}

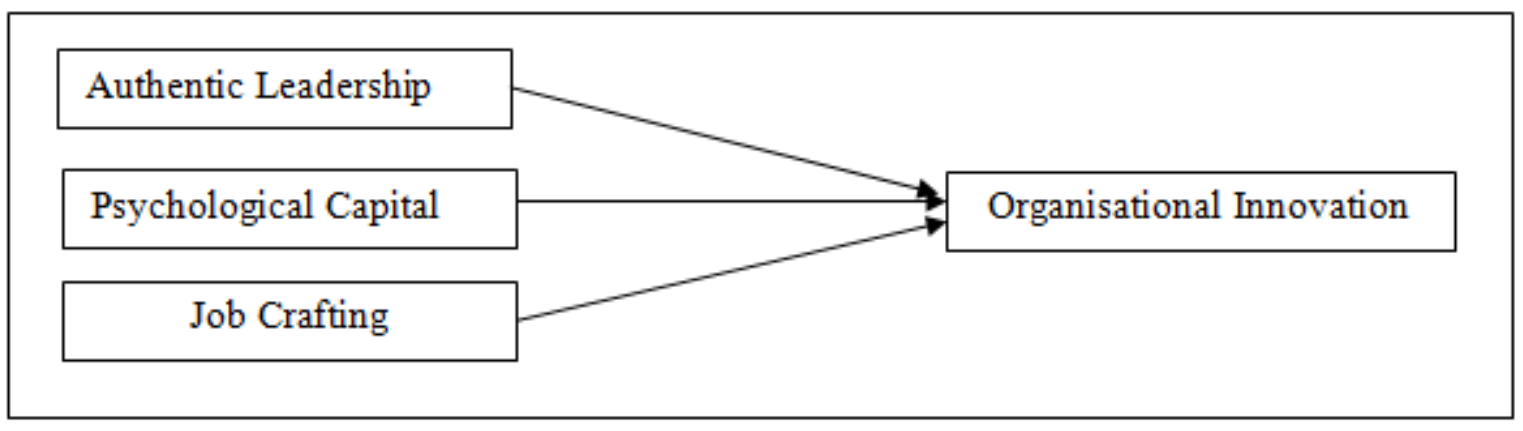

Figure 1: Conceptual Framework 


\section{Methodology}

\subsection{Sampling Frame and Sampling Technique}

In this study conducted in Thailand, the researcher selected to collecting data from companies listed on the Stock Exchange of Thailand in the financial business industry category, which total 70 companies. Specifically, this study adopted a multi-stage sampling technique for the selection of the respondents. In the first stage, the researcher used the area sampling technique by dividing the population into smaller groups based on their geographic locality, including North, Northeast, Central, and Southern. The researcher randomly took the samples by region, selecting the provinces representing each region and choosing provinces that contributed to high economic and social growth. In the second stage, the researcher used a stratified sampling technique for selecting the organisation and determined the number of organisations selected from each region, a total of 70 companies. In the third stage, the researcher used simple random sampling for selecting the respondents from each organisation.

\subsection{Response Rate}

The data collection process was carried out for three months. From 600 hand-distributed administered survey questionnaires, 482 questionnaires were received; from 500 survey questionnaires distributed by post, 70 questionnaires were returned. Then, out of 600 survey questionnaires administered online, 173 questionnaires were completed. Therefore, a total of 725 completed survey questionnaires were obtained. 42 of them were discarded due to inappropriate responses, e.g., a predisposition to agree regardless of the question, or a preference for extreme opposites, or a mid-point answer collection. Hence, 683 questionnaires were finally used. This study had a response rate of 40.17 per cent.

\subsection{Data Collection Process}

Prior to the questionnaire distribution, researchers obtained permission from the manager or CEO of the company. The researchers provided a cover letter that detailed the study, such as research topics, research objectives, etc. The respondents were informed regarding the details of the study objectives and the collected data were kept anonymous. The respondents were asked to fill out basic information about themselves and authentic leadership, organisational innovation, psychological capital, and job crafting. When the survey was completed, each respondent was asked to return the survey to the researchers on the same day or in the following week.

\subsection{Measures}

As a measure of authentic leadership, the scale designed by Neider and Schriesheim (2011) was used. The scale comprised 16 items on a 5-point Likert scale, with 1 demonstrating strong disagreement and 5 displaying strong agreement. The example for the item included "My leader solicits feedback for improving his/her dealings with others" and "My leader accurately describes the way that others view his/her abilities."

For psychological capital measurement, the scale designed by Luthans et al. (2007) was used. The scale had 20 items measured on a 5-point Likert scale, with 1 demonstrating strong disagreement and 5 displaying strong agreement. The examples for the item were "You are confident that you are the one person who will help set the goals of the organisation" and "You see that there will be good things in your work in the future."

To measure job crafting, the scale designed by Lee et al. (2017) was applied. The scale consisted of 15 items on a 5 point Likert scale, with 1 demonstrating strong disagreement and 5 displaying strong agreement. The items involved "I change the scope or types of tasks that I complete at work" and "I make friends with people at work who have similar skills or interests."

As a measure of organisational innovation, the scale designed by Wang and Ahmed (2004) was employed. The scale contained 20 items measured on a 5-point Likert scale, with 1 demonstrating strong disagreement and 5 displaying strong agreement. The items, for example, were "In comparison with our competitors, our company has introduced more innovative products and services during the past five years" and "We encourage people to think and behave in original and novel ways."

The researcher translated the questionnaire items from English to Thai before the distribution. An English teacher who is Thai did the translation. The re-interpreted form in English was correlated with the original English form; no significant differences were observed.

\subsection{Reliability and Validity Tests}

The validity test is Kaiser-Meyer-Olkin (KMO) and Bartlett's test of sphericity, whereas the reliability test is Cronbach's alpha. The total variable values are reliable with a Cronbach's alpha value greater than .60, and the KMO and Bartlett's test values are accurate with a value of.905. 
Rachadatip Uppathampracha, Liu Guoxin

A Study on the Relationships between Authentic Leadership, Job Crafting,

Psychological Capital and Organisational Innovation

Table 1: Cronbach's Alpha Test

\begin{tabular}{lll}
\hline Variables & Number of Items & Cronbach's Alpha value \\
\hline Authentic leadership & 16 & 0.95 \\
Psychological capital & 20 & 0.95 \\
Job crafting & 15 & 0.94 \\
Organisational innovation & 20 & 0.96 \\
\hline
\end{tabular}

Table 2: Kaiser-Meyer-Olkin (KMO) and Bartlett's Test of sphericity

\begin{tabular}{lll}
\hline Kaiser-Meyer-Olkin Measure of Sampling Adequacy & & 0.976 \\
\hline Bartlett's Test of Sphericity & Approx. Chi-Square & 39230.97 \\
& Df & 2485 \\
& Sig. & 0.00 \\
\hline
\end{tabular}

\subsection{Data Analysis}

The SPSS program, version 24.0, was used for all data analysis. Descriptive statistics are used to analyse demographic data-for example, frequency, percentage, mean, and standard deviation. Multiple Regression Analysis is applied in this study to test the hypothesis by predicting the factors' effects (Authentic leadership, Psychological capital, Job

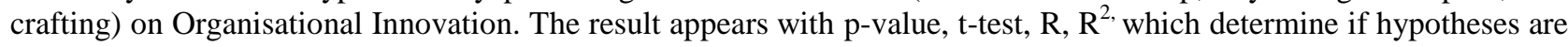
accepted or rejected.

\section{Result}

The respondents' demographic profile in the present research was presented in Table 3, displaying the demographic characteristics, e.g. gender, age, education, and job position. As seen in Table 5.1, females made up the majority of the respondents (74.8\%). Furthermore, most respondents were 31-40 years old (42.5\%). Concerning the level of education, $73.2 \%$ of the respondents had a Bachelor's degree. Besides, $77.6 \%$ of the respondents were employed as staff in the company.

\begin{tabular}{llcc}
\multicolumn{4}{c}{ Table 3: The Demographic Profiles of the Respondents } \\
\hline \multicolumn{1}{c}{ Demographic Variable } & \multicolumn{1}{c}{ Category } & Frequency & Percent (\%) \\
\hline Gender & Male & 172 & 25.20 \\
& Female & 511 & 74.80 \\
\hline Age & Under 20 years & 3 & 0.40 \\
& $21-30$ years & 221 & 32.40 \\
& $31-40$ years & 290 & 42.50 \\
& 41-50 years & 117 & 17.10 \\
& 51-60 year & 52 & 7.60 \\
\hline Education & Senior High School & 5 & 0.70 \\
& Diploma & 4 & 0.60 \\
& Bachelor's degree & 500 & 73.20 \\
& Master's degree & 163 & 24.00 \\
& Ph.D. & 10 & 1.50 \\
\hline Job position & Staff & 523 & 76.60 \\
& Primary-level executive & 89 & 13.00 \\
& Middle-level executive & 50 & 7.30 \\
\hline Total & Higher-level executive & 21 & 3.10 \\
\hline
\end{tabular}

Meanwhile, the distribution of the main variables scores was demonstrated in Table 4. The mean and standard deviation were observed to determine the respondents' level of Authentic leadership, Organisational Innovation, Psychological capital, and Job crafting. It demonstrates that the level of Authentic leadership, Organisational Innovation, Psychological capital, and Job crafting of the respondents are high.

Table 4: Mean and Standard Deviation of Variables Scores

\begin{tabular}{|l|c|c|c|}
\hline Variables & $\bar{X}$ & SD & Levels \\
\hline Authentic leadership & 3.92 & 0.79 & High \\
\hline Organisational innovation & 3.91 & 0.77 & High \\
\hline Psychological capital & 3.96 & 0.65 & High \\
\hline Job crafting & 3.97 & 0.62 & High \\
\hline
\end{tabular}

\subsection{Hypothesis testing}




\section{H1: Authentic leadership is positively related to organisational innovation.}

From Table 5, under the condition of the significant level $(\alpha=0.05)$, multiple linear regression analyses result indicated a positive relationship direction of Authentic leadership to forecast organisational innovation, which could explain the variance in organisational innovation about $40 \%$. There was a correlation coefficient equal to.64, which gave an equation to predict factors that impacted organisational innovation as follows:

Organisational innovation $=1.52+.61$ (authentic leadership)

Table 5: Multiple Linear Regression analysis results of Authentic leadership is positively related to organisational innovation

\begin{tabular}{|l|c|c|c|c|c|}
\hline \multicolumn{1}{|c|}{ Variable } & B & S.E. & Beta & t & Sig. \\
\hline Authentic leadership & 0.61 & 0.03 & 0.63 & 21.49 & 0.00 \\
\hline Constant & 1.52 & 0.11 & & 13.556 & 0.00 \\
\hline
\end{tabular}

$\mathrm{R}=.64, \mathrm{SEE}=.52, \mathrm{R}^{2}=.40, \mathrm{R}^{2}$ adj $=.40, \mathrm{~F}=461.49, \quad$ Sig. of $\mathrm{F}=.00 \mathrm{p}<.05$

\section{H2: Psychological capital is positively related to organisational innovation.}

From Table 6, under the condition of the significant level $(\alpha=.05)$, multiple linear regression analyses result uncovered a positive relationship direction of psychological capital to forecast organisational innovation, which could predict the variance in organisational innovation around $41 \%$. There was a correlation coefficient equal to.64, which gave an equation to predict factors that impacted organisational innovation as follows:

Organisational innovation $=.99+.73$ (Psychological capital)

Table 6: Multiple Linear Regression analysis results of Psychological capital is positively related to organisational innovation

\begin{tabular}{|l|c|c|c|c|c|}
\hline \multicolumn{1}{|c|}{ Variable } & B & S.E. & Beta & t & Sig. \\
\hline Psychological capital & 0.73 & 0.03 & 0.64 & 21.89 & 0.00 \\
\hline Constant & 0.99 & 0.13 & & 7.402 & 0.00 \\
\hline
\end{tabular}

$\mathrm{R}=.64, \mathrm{SEE}=.52, \mathrm{R}^{2}=.41, \mathrm{R}^{2}$ adj $=.41, \quad \mathrm{~F}=479.58, \quad$ Sig. of $\mathrm{F}=.00, \mathrm{p}<.05$

\section{H3: Job crafting is positively related to organisational innovation.}

From Table 7, under the condition of the significant level $(\alpha=.05)$, multiple linear regression analyses result revealed a positive relationship direction of job crafting to forecast organisational innovation, which could explain the variance in organisational innovation approximately $40 \%$. There was a correlation coefficient equal to.63, which gave an equation to predict factors that impacted organisational innovation as follows: Organisational innovation $=1.09+.70$ (Job crafting)

Table 7: Multiple Linear Regression analysis results of Job crafting is positively related to organisational innovation

\begin{tabular}{|l|c|c|c|c|c|}
\hline \multicolumn{1}{|c|}{ Variable } & B & S.E. & Beta & t & Sig. \\
\hline Job crafting & 0.70 & 0.03 & 0.63 & 21.33 & 0.00 \\
\hline Constant & 1.09 & 0.13 & & 8.249 & 0.00 \\
\hline
\end{tabular}

$\mathrm{R}=.63, \mathrm{SEE}=.52, \mathrm{R}^{2}=.40, \mathrm{R}^{2}$ adj $=.40, \quad \mathrm{~F}=455.26, \quad$ Sig. of $\mathrm{F}=.00, \mathrm{p}<.05$

\section{Discussion and Conclusion}

This study examined the influence of authentic leadership, psychological capital, and job crafting on organisational innovation of the financial business sector in Thailand. It proved all the created hypotheses: 1) authentic leadership was positively related to organisational innovation, 2) psychological capital was positively related to organisational innovation, and 3) job crafting was positively related to organisational innovation.

For the first hypothesis, it was recommended that authentic leadership and organisational innovation would have a positive and significant relationship. $(\beta=.61, \mathrm{t}=21.49, \mathrm{p}=0.00)$. This result sustains the previous empirical findings on authentic leadership and organisational innovation (Gumusluoglu \& Ilsev, 2009; Jung et al., 2003; Walumbwa et al., 2008; Yuan \& Woodman, 2010). The knowledge and skill promote the impression of authentic leadership in their leader, contributing to organisational innovation. Such type of leadership encourages employees to create a new method and challenge their beliefs and inspires them to go beyond routine work and let them think out of the box, this is a basis for innovation. 


\section{Rachadatip Uppathampracha, Liu Guoxin}

In the second hypothesis, it was confirmed that psychological capital and organisational innovation had a positive and significant relationship $(\beta=.73, \mathrm{t}=21.89, \mathrm{p}=.00)$. This result corresponds with other researchers' findings on psychological capital enhancing organisational innovation (Abbas \& Raja, 2015; Rego et al., 2012; Sweetman et al., 2011). Psychological capital through self-efficacy, the state of the employees who is confident in their ability, knowledge, and skills to deal with challenging work. Similarly, through hope, psychological capital is the characteristic of an employee who commits to perform various activities to achieve the set goals. Correspondingly, psychological capital through resiliency which the characteristic of an employee who can manage things quickly, flexibly, and rebound swiftly. Finally, through optimism, psychological capital is the characteristic of an employee who positive thoughts or a positive perspective in explaining situations and accepting mistakes in work. Once mistakes are accepted, they can start over again.

In the third hypothesis, this study observed a positive and significant relationship between job crafting and organisational innovation $(\beta=.70, \mathrm{t}=21.33, \mathrm{p}=0.00)$. This result supports other researchers' findings on job crafting enhancing organisational Innovation (Bakker \& Demerouti, 2007; Kooij et al., 2017; Robledo et al., 2019). Job crafting through task crafting, which adds mission focused on something more specific in tasks that employees craft daily. Similarly, job crafting through cognitive crafting, the employees thinking about theirs work as well as sustained mentally and physically exertion or skills in their work. Finally, job crafting, through relational crafting, helps employees arrange for themselves to manage their work. As mentioned previously, job crafting enables employees to create innovation for the organisation.

\subsection{Recommendations}

The findings contribute concrete suggestions for managers who require to foster innovation in their organisations. Specifically, the findings indicate that authentic leadership can affect organisational innovation positively. Therefore, top management should focus on authentic leadership; clearly and effectively communicate the organisational objectives, policies, and decisions in offering top management and middle management training about how to be authentic leadership. This would help promote understanding the new role of the leader in the organisation.

Furthermore, the study results also indicate that psychological capital and job crafting are having a positive effect on organisational innovation. To put it another way, encouragement of psychological capital and job crafting stimulates the organisation's effectiveness. Psychological capital supports the employees in the state of confidence in their ability, knowledge, and skills that they have to deal with challenging work and commits to perform various activities to achieve the set goals. Besides, employees can control emotions, a positive perspective in explaining situations, and happy at work.

Significantly, creating an innovative organisation should require job crafting, which freedom of thought for the employees so that they can use their expertise to work to achieve their goals. Moreover, employees should be rewarded with appropriate opportunities to demonstrate acceptance of creativity and innovation that advantage the organisation. It shows the importance of employee work and stimulates employees to be innovative thinking continuously. It may be said, discovering and championing techniques that enhance psychological capital and job crafting, including the encouragement from a leader who has the qualities of authentic leadership, are seen as the path to achieving organisational innovation

Consequently, if an organisation desires to develop itself and become an innovative organisation, it should pay more attention to those factors. In a nutshell, this cohesive approach would facilitate employees in developing a deeper understanding of organisational innovation signs and positive expectations of innovation for the employee to advance to an innovative organisation.

\subsection{Limitations}

The current research design is cross-sectional. It is confessed that the data for this research was done at a certain point in time. The cross-sectional type data can only measure degrees of relationship between variables since it is unable to infer causality. Cause-effect relationships can only be derived to a limited degree from the results because of the crosssectional type design. Furthermore, the data were obtained through self-reporting of the employees. It was thought to be fitting because workers would be in the best position to report their interpretations of the variables studied. However, there is a chance that the employees are not completely right, which may lead to a bias in the findings. (Wright, Gardner, \& Moynihan, 2003).

\subsection{Future Research}

This research focuses on employees of Thailand's financial business organisations working in the private sector. In the future, the study should include other types of organisations, For example, technology, production, or service. Additionally, the other construct influencing organisational innovation should be increased in the prediction equation. Also, the other factors that impact organisational innovation should be investigated to the difference between financial 
business and another business. Moreover, it can also analyse among government organisations, state enterprises organisations, and private organisations. Besides, future research should investigate the mediator and moderator relationships between authentic leadership and organisational innovation, including the psychological capital and organisational innovation and job crafting and organisational innovation.

\section{References}

- Abbas, M., \& Raja, U. (2015). Impact of psychological capital on innovative performance and job stress. Canadian Journal of Administrative Sciences/Revue Canadienne des Sciences de l' Administration. CrossRef

- Avolio, B. J., \& Gardner, W. L. (2005). Authentic leadership development: Getting to the root of positive forms of leadership. The leadership quarterly. $\underline{\text { CrossRef }}$

- Avolio, B. J., \& Mhatre, K. H. (2012). Advances in theory and research on authentic leadership. In Gretchen M. Spreitzer and Kim S. Cameron (Eds.), The Oxford handbook of positive organisational scholarship (pp.4). Oxford University Press. $\underline{\text { CrossRef }}$

- $\quad$ Bakker, A. B., \& Demerouti, E. (2007). The job demands-resources model: State of the art. Journal of managerial psychology. $\underline{\text { CrossRef }}$

- $\quad$ Berg, J. M., Dutton, J. E., \& Wrzesniewski, A. (2008, January 8). What is job crafting and why does it matter? Regents of the University of Michigan.

- Burns, P. (2011). The economics of entrepreneurship and public policy. In N. Jayatunga (Ed.), Entrepreneurship and small business. New York: Palgrave Macmillan. CrossRef

- Damanpour, F., Walker, R. M., \& Avellaneda, C. N. (2009). Combinative effects of innovation types and organisational performance: A longitudinal study of service organisations. Journal of management studies. CrossRef

- George, B. (2003). Becoming an Authentic leader. In W.Bennis (Ed.), Authentic leadership: Rediscovering the secrets to creating lasting value. California: John Wiley \& Sons. CrossRef

- Giallonardo, L. M., Wong, C. A., \& Iwasiw, C. L. (2010). Authentic leadership of preceptors: Predictor of new graduate nurses' work engagement and job satisfaction. Journal of nursing management. CrossRef

- Gumusluoglu, L., \& Ilsev, A. (2009). Transformational leadership, creativity, and organisational innovation. Journal of business research. $\underline{\text { CrossRef }}$

- Jafri, H. (2012). Psychological capital and innovative behaviour: An empirical study on apparel fashion industry. Journal of Contemporary Management Research. CrossRef

- Jung, D. I., Chow, C., \& Wu, A. (2003). The role of transformational leadership in enhancing organisational innovation: Hypotheses and some preliminary findings. The leadership quarterly. CrossRef

- Kernis, M. H. (2003). Toward a conceptualization of optimal self-esteem. Psychological inquiry. $\underline{\text { CrossRef }}$

- Kooij, D. T., van Woerkom, M., Wilkenloh, J., Dorenbosch, L., \& Denissen, J. J. (2017). Job crafting towards strengths and interests: The effects of a job crafting intervention on person-job fit and the role of age. Journal of applied psychology. CrossRef

- Larson, M., \& Luthans, F. (2006). Potential added value of psychological capital in predicting work attitudes. Journal of leadership \& organisational studies. CrossRef

- Lee, S.-H., Shin, Y., \& Baek, S. I. (2017). The impact of job demands and resources on job crafting. Journal of Applied Business Research (JABR). $\underline{\text { CrossRef }}$

- Lopez, S. J., Pedrotti, J. T., \& Snyder, C. R. (2018). Positive environments. In L.Parra (Ed.), Positive psychology: The scientific and practical explorations of human strengths.California: Sage Publications. CrossRef

- Luthans, F., Avolio, B. J., Avey, J. B., \& Norman, S. M. (2007). Positive psychological capital: Measurement and relationship with performance and satisfaction. Personnel psychology. $\underline{\text { CrossRef }}$

- Luthans, F., Luthans, K. W., \& Luthans, B. C. (2004). Positive psychological capital: beyond human and social capital. Business Horizons. $\underline{\text { CrossRef }}$

- Luthans, F., \& Youssef, C. M. (2004). Human, social, and now positive psychological capital management: Investing in people for competitive advantage. Organisational Dynamics. CrossRef

- Müceldili, B., Turan, H., \& Erdil, O. (2013). The influence of authentic leadership on creativity and innovativeness. Procedia-Social and Behavioural Sciences. CrossRef

- Neider, L. L., \& Schriesheim, C. A. (2011). The authentic leadership inventory (ALI): Development and empirical tests. The leadership quarterly. $\underline{\text { CrossRef }}$

- Rego, A., Sousa, F., Marques, C., \& e Cunha, M. P. (2012). Authentic leadership promoting employees' psychological capital and creativity. Journal of business research. CrossRef

- Robledo, E., Zappalà, S., \& Topa, G. (2019). Job Crafting as a Mediator between Work Engagement and Wellbeing Outcomes: A Time-Lagged Study. International journal of environmental research and public health. CrossRef

- Salancik, G. R., \& Pfeffer, J. (1978). A social information processing approach to job attitudes and task design. Administrative science quarterly. CrossRef 
- Sweetman, D., Luthans, F., Avey, J. B., \& Luthans, B. C. (2011). Relationship between positive psychological capital and creative performance. Canadian Journal of Administrative Sciences/Revue Canadienne des Sciences de l'Administration. CrossRef

- Tidd, J., \& Bessant, J. (2018). Building the Innovative Organisation. In J. Manias (Eds.), Managing innovation: Integrating technological, market and organisational change. John Wiley \& Sons Inc. CrossRef

- Toor, S. U. R., \& Ofori, G. (2009). Authenticity and its influence on psychological well-being and contingent selfesteem of leaders in Singapore construction sector. Construction Management and Economics. CrossRef

- Uejirapongpan, S., Wattanasin, P., Chanchai, A., \& Kuprat, P. (2010). Innovation: Definition, type, and importance of entrepreneurship. Journal of Business Administration. CrossRef

- Van Wingerden, J., Bakker, A. B., \& Derks, D. (2017). Fostering employee well-being via a job crafting intervention. Journal of Vocational Behaviour. CrossRef

- Van Wingerden, J., Derks, D., \& Bakker, A. B. (2017). The impact of personal resources and job crafting interventions on work engagement and performance. Human Resource Management. CrossRef

- Walumbwa, F. O., Avolio, B. J., Gardner, W. L., Wernsing, T. S., \& Peterson, S. J. (2008). Authentic leadership: Development and validation of a theory-based measure. Journal of management. CrossRef

- Wang, C. L., \& Ahmed, P. K. (2004). The development and validation of the organisational innovativeness construct using confirmatory factor analysis. European journal of innovation management. CrossRef

- Wright, P. M., Gardner, T. M., \& Moynihan, L. M. (2003). The impact of HR practices on the performance of business units. Human Resource Management Journal. CrossRef

- Wrzesniewski, A., \& Dutton, J. E. (2001). Crafting a job: Revisioning employees as active crafters of their work. Academy of management review. CrossRef

- Yuan, F., \& Woodman, R. W. (2010). Innovative behaviour in the workplace: The role of performance and image outcome expectations. Academy of Management Journal. $\underline{\text { CrossRef }}$ 